\title{
Early Growth Assessment of Selected Exotic and Indigenous Tree Species in Nigeria
}

\section{Alfred Ossai Onefeli ${ }^{1 凶}$, Peter Oluremi Adesoye ${ }^{1}$}

1 University of Ibadan, Faculty of Agriculture and Forestry, Department of Forest Resources Management, Ibadan, Nigeria

$\triangle$ Corresponding author: e-mail: ftaxonomist@gmail.com

Citation:

ONEFELI A O, ADESOYE P O 2014 Early Growth Assessment of Selected Exotic and Indigenous Tree Species in Nigeria. South-east Eur for 5 (1): 45-51. DOI: http://dx.doi.org/10.15177/seefor.14-06

\section{Abstract}

Background and Purpose: Nigeria is greatly endowed with numerous tree species of which majority of them are native while few are exotic. Report shows that high percentage of man-made forests in the country is dominated with exotic species. This culminated from the assumption that exotic trees are fast growing. However, this study investigated the growth of indigenous trees in tandem with that of exotic species with a purpose to clarify the assumption about the growth and conservation of indigenous species in natural forests.

Materials and Methods: The study was conducted at the nursery unit of the Department of Forest Resources Management, University of Ibadan, Nigeria. Five (5) different one year old tree species seedlings were used for the study. Two of the species (Tectona grandis and Gmelina arborea) are exotic while the other three species (Khaya senegalensis, Khaya grandifolia and Afzelia africana) are native to Nigeria. They were planted on the field in a completely random design and then replicated eight times. Data were collected every month on their height growth, collar diameter and leaf number. Data obtained were subsequently analyzed with ANOVA.

Results and Conclusions: Results show that $K$. grandifolia $(45.39 \mathrm{~cm})$ grew significantly better $(p<0.05)$ in height than G. arborea $(38.11 \mathrm{~cm})$ and $T$. grandis $(22.36 \mathrm{~cm})$, while $A$. africana $(40.03$ $\mathrm{cm}$ ) closely followed $K$. grandifolia. Based on the results, the selected indigenous species displayed promising potentials for conservation purpose. Hence, further research in this aspect is encouraged to confirm the findings.

Keywords: height growth, collar diameter growth, Tectona grandis, Gmelina arborea, Khaya senegalensis, Khaya grandifolia, Afzelia africana

\section{INTRODUCTION}

Forest resources are renewable natural resources and Nigeria as a nation is copiously gifted with these resources [1]. Of all the forest resources, trees have been categorized as the major produce based on the high economic value generated from them. Ecologically, trees 
can be further classified into indigenous and exotic taxon. A tree species is regarded as native or indigenous to a given region or ecosystem if its presence in that region is the result of natural processes, with no human intervention. Every natural organism has its own natural range of distribution in which it is regarded as native. There are numerous indigenous tree species in Nigeria that have equivalent timber quality or better timber quality than the exotic species [1]. These include Milicia excelsa, Entandrophragma spp. Khaya senegalensis, Khaya grandifolia Mansonia altissima, Albizia zygia, Afzelia africana, etc.

Exotic tree species on the other hand is a species living outside its native distributional range, which has arrived there by human activity, either deliberately or accidentally. There are various economic tree species that are exotic to Nigeria, but the two widely known and cultivated species are Tectona grandis and Gmelina arborea. In other words, these two species dominate various forest plantations in Nigeria [2-4]. However, majority of these plantations are monospecific, which is ecologically detrimental to the environmental balance of forest biodiversity. Additionally, reports have revealed that some exotic tree species have tremendous damaging impact on the indigenous trees as well as other natural resources in the forest or the ecosystem. For instance, they cause decline in abundance, contraction of geographic ranges, and extinction of native species [5-7]. According to Nwoboshi [8], Tectona grandis does not support the growth of some indigenous trees because of its allelopathic nature. In other words, where $T$. grandis is grown, economic indigenous tree species like Mansonia altissima, Ricinodendron heudelotii, and Albizia zygia cannot survive [8]. Apart from the environmental issues caused by exotic species, there are also problems of meeting the livelihood and cultural needs of the local communities that depend on forest products and services [9]. For instance, a study [1] has shown that parts of indigenous tree species are used by masquerades as paraphernalia during cultural festival in some villages in southwestern Nigeria. In this case, exotic tree species cannot be used as surrogates for indigenous species. In addition, it is interesting to know that Gmelina arborea, which has been formally categorized as less known species is being utilized for our major forest restoration in Nigeria. The species was originally introduced to Nigeria for pulping purpose. As a result of the fact that it overgrew the stage of its utilization for pulp and paper in tandem with unavailability of better indigenous timber species in the natural forest, it is now being utilized for timber purpose.

Generally, it is believed that exotic trees in Nigeria grow faster than indigenous trees, although, there is no pragmatic research to corroborate this fact. Hence, this general belief has encouraged a higher level of conservation of exotic tree species than of our indigenous tree species [8]. According to Emtage [10], the established supply chain and generally more rapid growth rates of exotic species have led to them being favored for plantation use rather than the indigenous species. Hence, the indigenous tree species are perpetually being neglected while the exotic species are encouraged. Due to the promotion of exotic trees for plantation purposes, the indigenous are being threatened in the natural forests [1-2]. In order to conserve the threatened indigenous tree species in natural forests of Nigeria, it is expedient that the early growth of indigenous and exotic trees is simultaneously studied.

There are studies [11-12] which have assessed the early growth of some trees in Nigeria, but none has been able to simultaneously study the growth of indigenous and exotic trees. For instance, Gbadamosi et al. [11] studied the effect of four provenances on early seedling growth of Parkia biglobosa and discovered the provenance of Ibadan to have the best growth. They recommended that the seed of the species should be sourced from lbadan if its plantation is to be established. According to Mohammed et al. [12], height growth of Balanites aegyptiaca can be very slow at the seedlings stage, but at the saplings stage, the growth rate increases drastically. This paper therefore investigated the early growth of selected indigenous trees in tandem with that of exotic species with a purpose to clarify the assumption about the growth and conservation of indigenous species in natural forests. 


\section{MATERIALS AND METHODS}

This study was embarked upon at the nursery unit of the Department of Forest Resources Management, University of Ibadan. The site is located approximately on latitude $07^{\circ} 26.981^{\prime} \mathrm{N}$ and longitude $0003^{\circ} 53.733^{\prime} \mathrm{E}$. It is at an altitude of $277 \mathrm{~m}$ above sea level [8]. The annual rainfall of the area is $1258 \mathrm{~mm}-1437 \mathrm{~mm}$ with mean daily temperature ranges from $22^{\circ} \mathrm{C}-31^{\circ} \mathrm{C}$ and the soil of the area is ferric luvisols [8].

Five tree species were used for the study. Two species (Tectona grandis and Gmelina arborea) are exotic while the remaining three species; namely Khaya senegalensis, Khaya grandifolia and Afzelia africana are native to Nigeria. The exotic species were selected for this study due to their high rate of utilization while the native ones were used because they are severely threatened and almost extinct in Nigeria.

The seedlings used for this study, which were a year old, were obtained from the Department of Forest Resources Management Nursery. Each tree species was replicated eight times in a completely random design and planted on the area of $1 \mathrm{~m} \times 1 \mathrm{~m}$ on the field. However, the same environmental treatments were imposed on the tree species. In other words, they were all left to experience the real natural conditions on the field.

Data were collected every month in the period of six months on their height growth, collar diameter and leaf number. Height growth measurement was achieved by taking the vertical distance from the ground level to the tip of each tree using a long meter. Collar diameter was obtained by measuring the diameter at the collar point of the trees with the use of a vernier caliper while number of leaves on each tree was obtained by visual counting. Statistical analysis was carried out using a one way analysis of variance (ANOVA). Duncan Multiple range test was used for post hoc analysis.

\section{RESULTS}

Results (Figure 1) show that after a month of assessment, $G$. arborea increased in height for $7.03 \mathrm{~cm}$ and was the highest of all the species. It was followed by $K$. grandifolia ( 2.76 $\mathrm{cm}), A$. africana $(1.49 \mathrm{~cm}), K$. senegalensis $(1.23 \mathrm{~cm})$ and $T$. grandis $(0.7 \mathrm{~cm})$, which had the least height growth. The growth followed a similar pattern from the first month to the $4^{\text {th }}$ month $G$. arborea having the highest height growth while the least was recorded in $T$. grandis all throughout this period. However, at the $5^{\text {th }}$ month, the growth pattern changed. $K$. grandifolia overtook all other species in its height growth as it measured $34.49 \mathrm{~cm}$ while $G$. arborea measured $31.54 \mathrm{~cm}, A$. africana $(31.33$ $\mathrm{cm}), K$. senegalensis $(25.90 \mathrm{~cm})$ and $T$. grandis $(15.70 \mathrm{~cm})$. At the final assessment of the height growth, $K$. grandifolia still had the highest cumulative height increment of about $45 \mathrm{~cm}$; it was closely followed by $A$. africana $(40.03 \mathrm{~cm})$, while the species that had the least growth rate was $T$. grandis, with just $22.36 \mathrm{~cm}$ of height growth after six months. Table 1 shows that height increment differs significantly $(p<0.05)$ among the species.

The results of collar diameter increment are shown in Table 1 and Figure 2. Statistically, there was a significant difference in the collar diameter increment $(p<0.05)$ among the tree species after the period of six month. $G$. arborea depicted the highest average collar diameter increment (4.23 $\mathrm{cm}$ ) among the tree species, but it did not differ significantly from the three indigenous species (i.e. K. grandifolia [4.14 cm], A. africana [3.94 $\mathrm{cm}$ ] and $K$. senegalensis [3.90 cm]). In addition, as an exotic species, $T$. grandis was observed to be the species with the smallest collar diameter increment of $2.51 \mathrm{~cm}$.

During the assessment of leaf number over the period of the experiment (Table 1), K. grandifolia (26.7) has showed the highest leaf production compared to other species. The species that followed $K$. grandifolia was $K$. senegalensis (21.2), A. africana (19.0), and T. grandis (13.8) having the least number of leaves. Hence, statistical variation of the leaves produced amongst all the species showed a significant result $(p<0.05)$. The periodic change in the number of leaves from the first to sixth month of the experiment is shown in Figure 3. 


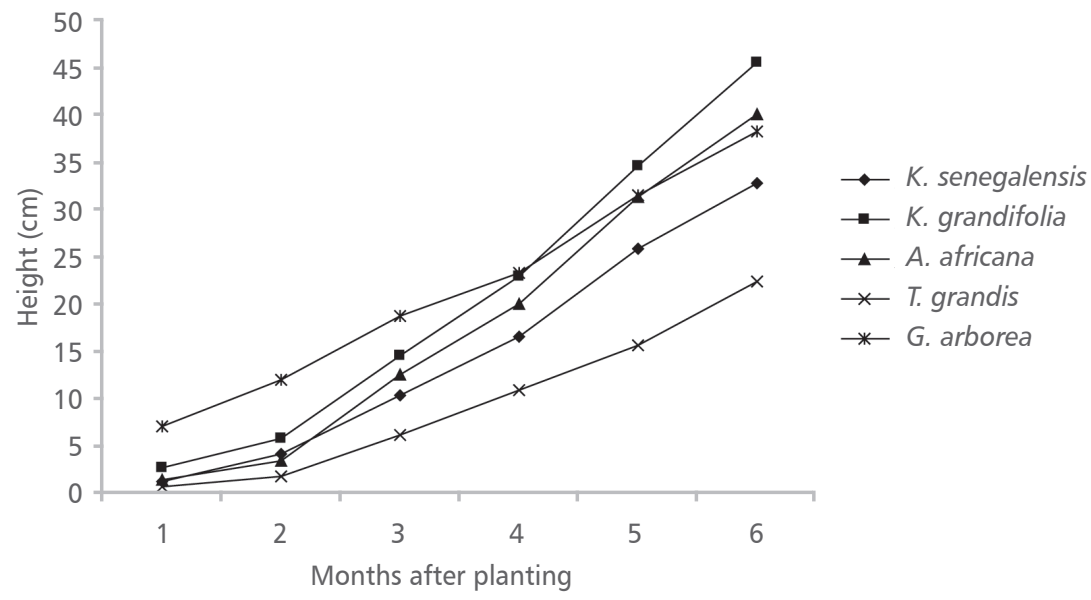

FIGURE 1. Height growth of the species after six months

TABLE 1. Increase in height, collar diameter and number of leaf of tree saplings

\begin{tabular}{lccc}
\hline \multicolumn{1}{c}{ Species } & $\begin{array}{c}\text { Height increment } \\
(\mathrm{cm})\end{array}$ & $\begin{array}{c}\text { Collar diameter increment } \\
(\mathrm{cm})\end{array}$ & $\begin{array}{c}\text { Number of leaf } \\
(\mathrm{n})\end{array}$ \\
\hline K. senegalensis & $32.64 \mathrm{c}$ & $3.90 \mathrm{a}$ & $21.4 \mathrm{~b}$ \\
K. grandifolia & $45.39 \mathrm{a}$ & $4.14 \mathrm{a}$ & $26.7 \mathrm{a}$ \\
A. africana & $40.03 \mathrm{~b}$ & $3.94 \mathrm{a}$ & $19.0 \mathrm{~b}$ \\
T. grandis & $22.36 \mathrm{~d}$ & $2.51 \mathrm{~b}$ & $13.8 \mathrm{c}$ \\
G. arborea & $38.11 \mathrm{~b}$ & $4.23 \mathrm{a}$ & $21.2 \mathrm{~b}$ \\
p-value & $0.000^{*}$ & $0.000^{*}$ & $0.000^{*}$ \\
\hline
\end{tabular}

Means with similar superscript within the same column of any set of species are not significantly different at $p=0.05$ * = significant $(p<0.05)$

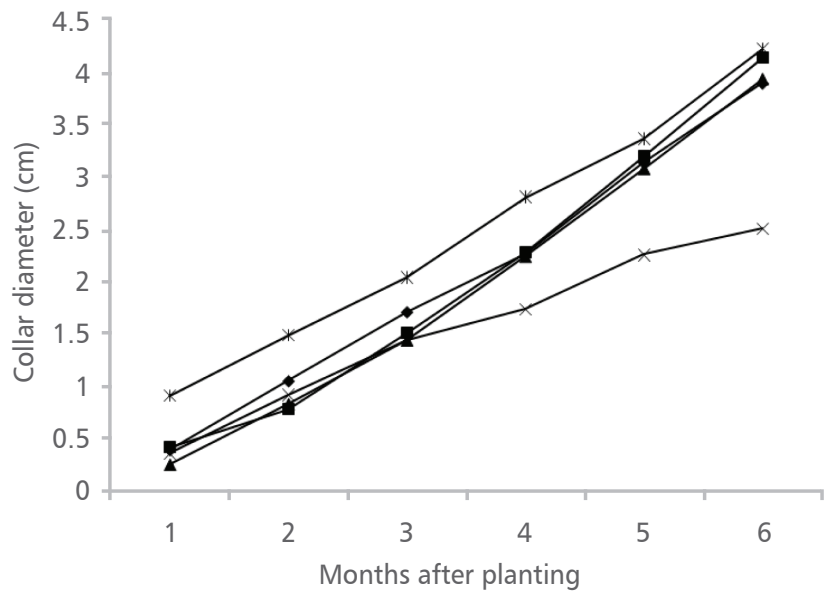

FIGURE 2. Collar diameter growth of the species after six months 


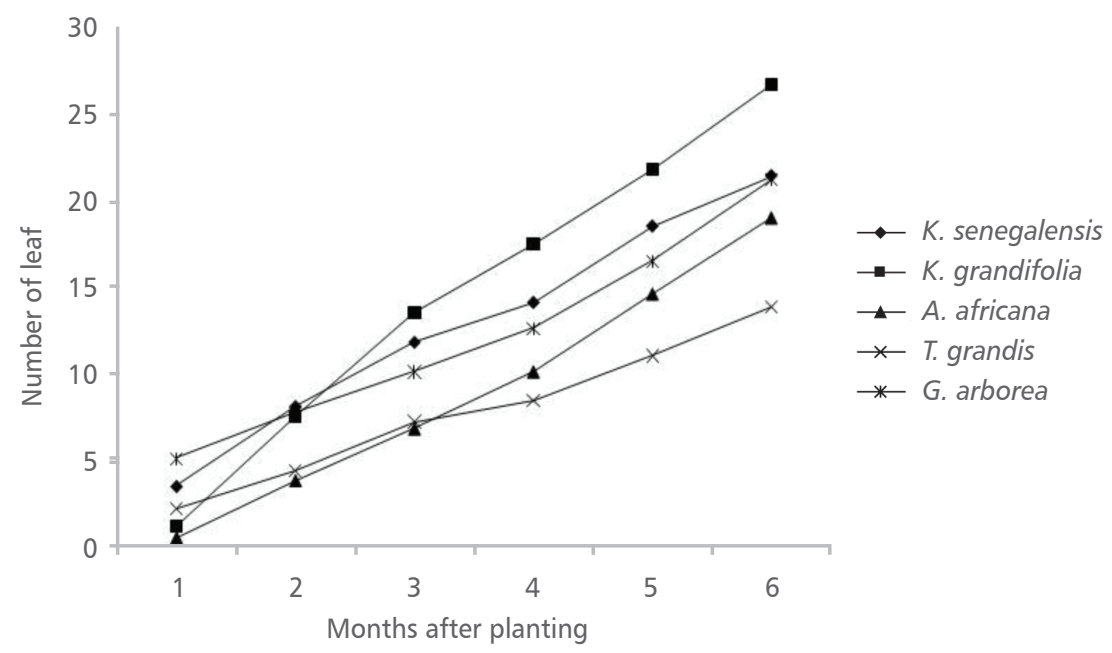

FIGURE 3. Number of leaf of the tree species after six months

\section{DISCUSSION}

The significant differences observed in the growth of the five tree species suggest that their level of adaptation to the same environmental conditions is more or less different. This may be ascribed to the combined effect of the environment and the inherent characteristics of the trees, which determines their physiognomy. The relatively better collar diameter growth rate observed in $G$. arborea than all other species at the initial stage may be due to its fast ability to transform photosynthate to growth at a seedlings' age $[6,13]$. This finding is in consonance with Mohammed et al. [12], who discovered that some trees can be very slow in growth at their tender age, but the rate of growth increases as they transcend to saplings age.

Generally, the sampled exotic species flourished and grew more rapidly at the initial period of assessment of the seedlings. As reported by some authors [13-15], these species are more favored to be used for plantation planting materials than our indigenous trees. However, in later stages, the indigenous species proved to have a better height and diameter increment than exotic species. Consequently, the findings of this study are in contrast to those of Gardner [16] and Zuidema et al. [17], who emphasized that exotic species performed better in growth compared to native species. For instance, Sarrailh and Ayrault, [8] stated that, with respect to tree height growth, exotic species ( $E$. grandis and $A$. saligna) performed better than indigenous species $(A$. polyacantha and $B$. thonningii) amongst all the species they experimented with and as such, concluded this has culminated with the fact that exotic species have been preferred because of their high growth rate. Interestingly, their study did not involve the sapling stage of the species but rather examined only the seedling stage. Conversely, this study agrees with Olukoye et al. [18], who recorded that exotic tree and shrub species showed a poorer performance in relation to indigenous species.

\section{CONCLUSION}

The study has been able to compare the growth rate of the exotic and the indigenous species up to the age of a year and half. The three indigenous species appeared promising. This is based on the fact that $K$. grandifolia grows better, both in height and diameter, at the saplings' age than the two most popularly known and propagated exotic species in Nigeria (i.e. G. arborea and $T$. 
grandis). However, further research is needed to ascertain this finding. In as much as this study is a preliminary study, further research in this regards can therefore focus more on the simultaneous growth of these at an older age. When this is achieved, ecologist and other tree growers as well as the tree planters will be encouraged to utilize them for the reforestation and afforestation in order to improve our degraded forests rather than using the exotic species. Hence, the threatened conservation status of the indigenous species in the natural forest would be ameliorated.

\section{REFERENCES}

1. IJEOMAH H M, AIYELOJA A A 2010 Ecotourism: An instrument for combating Renewable natural Resources Degradation. In: Ijeoma H M, Aiyeloja A A (eds) Practical Issues in Forest and wildlife Resources management. Green canopy consultants, Choba, Porthacourt, Nigeria, 625 p

2. ONI PI, JIMOH S O, ADEBISI L A 2014 Management of indigenous medicinal plants in Nigeria using phenological information. J Med Plants Res 8 (16): 619-631. DOI: http://dx.doi.org/10.5897/ JMPR2013.5108

3. ONOSODE A T 1988 Forest and Forest Industries in Nigeria. Obeche 22: 27-30

4. AIYELOJA A A, OGUNSANWO O $\mathrm{Y}$, ASIYANBI A P 2011 Determinants of Preference for LesserKnown Species among Cabinet-Makers in Oyo and Osun States, Nigeria. Small-scale Forestry 10 (1): 37-51. DOI: http://dx.doi.org/10.1007/ s11842-010-9129-8

5. ELTON C S 1958 The ecology of invasions by animals and plants. Methuen, London, UK, $15 \mathrm{p}$

6. EBENHARD T 1988 Introduced birds and mammals and their ecological effects. Swed Wildl Res 13: 1-107

7. FRITTS TH, RODDA G H 1998 The role of introduced species in the degradation of island ecosystems: a case history of Guam. Annu Rev Ecol Syst 29: 113-140. DOI: http://dx.doi.org/10.1146/annurev. ecolsys.29.1.113

8. SARRAILH J M, AYRAULT N 2001 Rehabilitation of Nickel Mining sites in New Caledonia. Unasylva 207 (52): 16-20

9. NWOBOSHI L C 1982 Tropical Silviculture: Principles and Techniques. Ibadan Univ. Press, Ibadan, Nigeria, 333 p
10. EMTAGE N F 2004 An Investigation of the Social and Economic Factors Affecting the Development of Small-scale Forestry by Rural Households in Leyte, Philippines. PhD thesis, The University of Queensland, School of Natural and Rural Systems Management, Gatton, Australia, $423 p$

11. GBADAMOSI A E, FABOYE O O, ONI O 2005 Seed Morphological Traits, Germination and Early Growth of Parkia biglobosa (Jacq.) R.Br. Ex. G. don from Four Provenances in Nigeria. Nigerian Journal of Forestry 35 (2): 129-137

12. MOHAMMED $H$ G, GOMBE $S H$, DOGARI J $Y$, BAPPAH M T, HINNA H B, IBRAHIM I 2013 The influence of Pre-germination Treatments on the emergence and early Growth of Balanites aegyptiaca (Linn. Delile) in Dadin Kowa, Gombe State. In: Popoola L, Idumah F O, Ogunsanwo 0 Y, Azeez I $O$ (eds) Proceedings of the $35^{\text {th }}$ annual conference of the forestry association of Nigeria (FAN), pp 69-74

13. FAO 1995 Forest resources assessment 1990 Tropical Forest Plantation resources. FAO Forestry Paper No 128. Food and Agriculture Organization of the United Nations, Rome, Italy. URL: http:// www.fao.org/docrep/007/v8330e/v8330e00. HTM\#TOC (10 January 2014)

14. AKINDELE S O, FUWAPE J A 1998 Wood-based industrial sector review. A consultancy report prepared as part of the national Forest Resources Study, Nigeria, $74 p$

15. ONYEKWELU J C 2001 Growth characteristics and management Scenarios for Plantation-grown Gmelina arborea \& Nauclea diderrichii in Southwestern Nigeria. Hieronymus Verlag, Münich, Germany, $196 p$

16. GARDNER J 2001 Rehabilitating mines to meet land use objectives: Bauxite mining in Jarrah forest of Western Australia. Unasylva 207 (52): 3-7 
17. ZUIDEMA $P$ A, BRIENEN $R$ J, DURING $H J$, GUNERALP B 2009 Do persistently fast-growing juveniles contribute disproportionately to population growth? A new analysis tool for matrix models and its application to rainforest trees. Am Nat 174 (5): 709-719. DOI: http:// dx.doi.org/10.1086/605981
18. OLUKOYE G A, WAMICHA W N, KINYAMARIO J I 2003 Assessment of the performance of exotic and indigenous tree and shrub species for rehabilitating saline soils of Northern Kenya. Afr J Ecol 41 (2): 164-70. DOI: http://dx.doi. org/10.1046/j.1365-2028.2003.00430.x 